\title{
Recruitment of damselfishes in One Tree Island lagoon: persistent interannual spatial patterns
}

\author{
David J. Booth ${ }^{1, *}$, Michael J. Kingsford ${ }^{2}$, Peter J. Doherty ${ }^{3}$, Giglia A. Beretta ${ }^{2}$ \\ ${ }^{1}$ Department of Environmental Sciences, University of Technology, Sydney, Westbourne Street, Gore Hill, \\ New South Wales 2065, Australia \\ ${ }^{2}$ School of Biological Sciences, University of Sydney, Sydney, New South Wales 2006, Australia \\ ${ }^{3}$ Australian Institute of Marine Science, PMB No. 3, Townsville MC, Queensland 4810, Australia
}

\begin{abstract}
The spatial and temporal patterns of distribution of new settlers of 23 species of damselfish (Pomacentridae) within One Tree Island lagoon, southern Great Barrier Reef (GBR) were measured for 3 summers to assess the persistence of spatial patterns of recruitment. Overall recruitment was 3 times higher in 1993/1994 than 1994/1995, and 1.5 times higher than 1999. In general, recruitment decreased towards the lagoon centre, even though habitat availability was not lower there on average, suggesting that most fish settled at outer sites as they were advected from adjacent waters. There was also great variation in numbers of recruits among outer sites. Patterns of recruitment to continuous reef and patch reef habitats also differed among species, suggesting habitat selection at this broad level. For example, Pomacentrus nagasakiensis was primarily found on patch reefs, while P. moluccensis was largely found on continuous reef. One site (Shark Alley) received the highest number of recruits of most species during the study, and this pattern has been observed in studies since 1975. Despite interannual variability in abundance of potential settlers and differences in the habitat preferences of some species, therefore, some sites on the reef can receive relatively high numbers of settlers over decadal time scales. This consistency of spatial pattern may be due to local topography and oceanography at Shark Alley, which appear to favour the input of potential settlers. The availability of live coral may also be important, but species which showed no preferences for live cover also recruited at high levels at this site. The attributes of Shark Alley were compared with those at other sites. Overall, sites that clustered on the basis of oceanographic and habitat features also had similar recruitment, suggesting that these features may be useful in predicting recruitment hotspots on reefs elsewhere.
\end{abstract}

KEY WORDS: Oceanographic features $\cdot$ Plumes $\cdot$ Pomacentrids $\cdot$ Recruitment $\cdot$ Settlement $\cdot$ Surf zones

Resale or republication not permitted without written consent of the publisher

\section{INTRODUCTION}

Great differences in the abundance of newly settled fish on coral reefs have been demonstrated among sites separated by 100 s of metres to 1000s of kilometres (Doherty \& Williams 1988). It is difficult, however, to determine the temporal persistence of these patterns unless sampling is done over many recruitment seasons. If persistent patterns of settlement are identified,

*E-mail: david.booth@uts.edu.au then the investigation of the physical and biological attributes of these sites may provide insight into the factors determining preferred settlement sites. Moreover, if there is a strong link between abundance of settlers and subsequent abundance of adults, then a knowledge of qualitative aspects of sites will improve understanding of adult population dynamics.

Factors that may be important determinants of fish recruitment include availability of suitable habitat, such as live corals (e.g., Booth \& Beretta 1994), damselfish territories (Green 1996), or conspecifics (e.g. 
Sweatman 1985, Booth 1992), oceanographic hotspots favouring larval retention (e.g., Kingsford et al. 1991, Doherty et al. 1997), prevalence of onshore winds (Milicich et al. 1992), and distance from the reef crest, creating a recruitment gradient (e.g., for seagrass invertebrates; Bell et al. 1988).

The relative role of passive dispersal and active larval behaviour in settlement has received little attention at the population level (i.e., how these processes affect distribution and abundance), but some authors have suggested that they have little influence at spatial scales relevant to population ecology (Doherty 1991, cf. Booth \& Wellington 1998). Availability of habitat in different reef zones may also drive distribution patterns of adult fishes (Williams 1979, Wellington 1992), adding a deterministic element to the stochastic supply of larvae to a site. As a consequence, a catastrophic loss of habitat, due to disturbances such as storms or massive predator buildup, may rapidly alter distribution of species (Wellington \& Victor 1985, Williams 1991). Other studies have shown that habitat availability can explain distribution of some species at local scales of $<100 \mathrm{~m}$, but could not account for among-site variability (e.g., Doherty 1982, Tolimieri 1995).

Sheltered, small, coral reef lagoons can have unique assemblages of fishes compared to open-reef areas, because of habitat differences and differences in advective processes that can restrict entry of larvae (e.g., Galzin et al. 1994, Kingsford \& Finn 1997). Some species of damselfish, for instance, apparently avoid lagoons compared to congenerics. Pomacentrus coelestis is rare inside One Tree Island lagoon, but common on adjacent reef slopes. These larvae may detect lagoonal waters including thermal plumes emanating from the lagoon, and so avoid entry (Doherty et al. 1996). If advective processes near lagoons are central to arrival of larvae, then synchronous peaks in settlement of similar species would be expected. Asynchrony may result from different behavioural responses among species, including avoidance, as mentioned above, but also habitat selection.

This study investigated the variability in recruitment among 9 sites within One Tree Island lagoon, southern Great Barrier Reef. We simultaneously measured habitat and oceanographic features and monitored recruitment for a suite of common damselfishes (Pomacentridae) at each site over 3 seasons. An important part of the study was inclusion of a site (Shark Alley) which has been identified in studies since 1975 (Williams 1979) as a 'hotspot' for recruitment. We wanted to determine if this pattern was persistent over 10s of years.

Our objectives were to: (1) determine hotspots for recruitment on continuous and patch reefs, within the lagoon (among and within sites), over several years; (2) compare patterns of recruitment with historic re- cords of recruitment at One Tree Island; (3) characterise habitat and oceanographic characteristics of Shark Alley and other sites with consistently high recruitment, and develop a simple predictive model to link these characteristics with recruitment differences among sites.

\section{METHODS}

Sites. Coral reef pomacentrid fishes settle mainly in the period December to March on the Great Barrier Reef (GBR) (Anderson et al. 1981, Williams \& Sale 1981). Recruitment was monitored from September 1993 to February 1994, from November 1994 to February 1995, and from January to February 1999 at 9 sites within One Tree Island lagoon (Fig. 1), southern GBR. The lagoon is $5 \mathrm{~km}$ long, with 5 sites established around the inside perimeter of the lagoon and 4 sites more centrally located. One Tree Island lagoon has a continuous coral rim, and as a result is ponded at low tide (i.e., water level inside the lagoon is higher than that of the surrounding ocean, Ludington 1979). On the flood tide, the influx of oceanic water is concentrated at several low points on the rim, notably near Shark Alley and the Gutter on the southeast side, and at the Entrance on the northeast rim (Fig. 1). The speed of water entering the lagoon at these locations is based on wind direction and speed, which in turn can influence larval influx to the lagoon (see Kingsford \& Finn 1997).

The reefs in the lagoon are mainly either continuous walls ('piecrust') or patch reefs in deeper (to $7 \mathrm{~m}$ ) water. The 9 sites included 5 'outer' sites (Shark Alley, Gutter, Sandflat, Entrance and First Bank), situated $<1 \mathrm{~km}$ from the reef edge, and 4 'inner' sites (Centre Bommie, Big Bommies, No Bommies and Maze; Fig. 1).

Species. Damselfishes (Pomacentridae) are ubiquitous and conspicuous members of coral reef fish assemblages, and most remain relatively sedentary once they arrive at the adult habitat. Several previous studies have monitored recruitment of damselfishes at One Tree Island (e.g., Russell et al. 1977, Williams 1979, Anderson et al. 1981, Williams \& Sale 1981, Doherty 1982, 1983, Jones 1987a,b, B. D. Mapstone unpubl.; Table 1), although none monitored recruitment on this scale, and few have monitored recruitment to continuous reef. The suite of species on continuous reef is different from those recruiting to patch reefs (cf. Williams 1980, Ault \& Johnson 1998) and comparison was drawn between recruitment in both habitats. Patch reefs were not sampled in 1999.

Recruitment monitoring. We define recruitment here to mean the appearance in the adult habitat within 2 wk of larval settlement in the reef habitat. At 


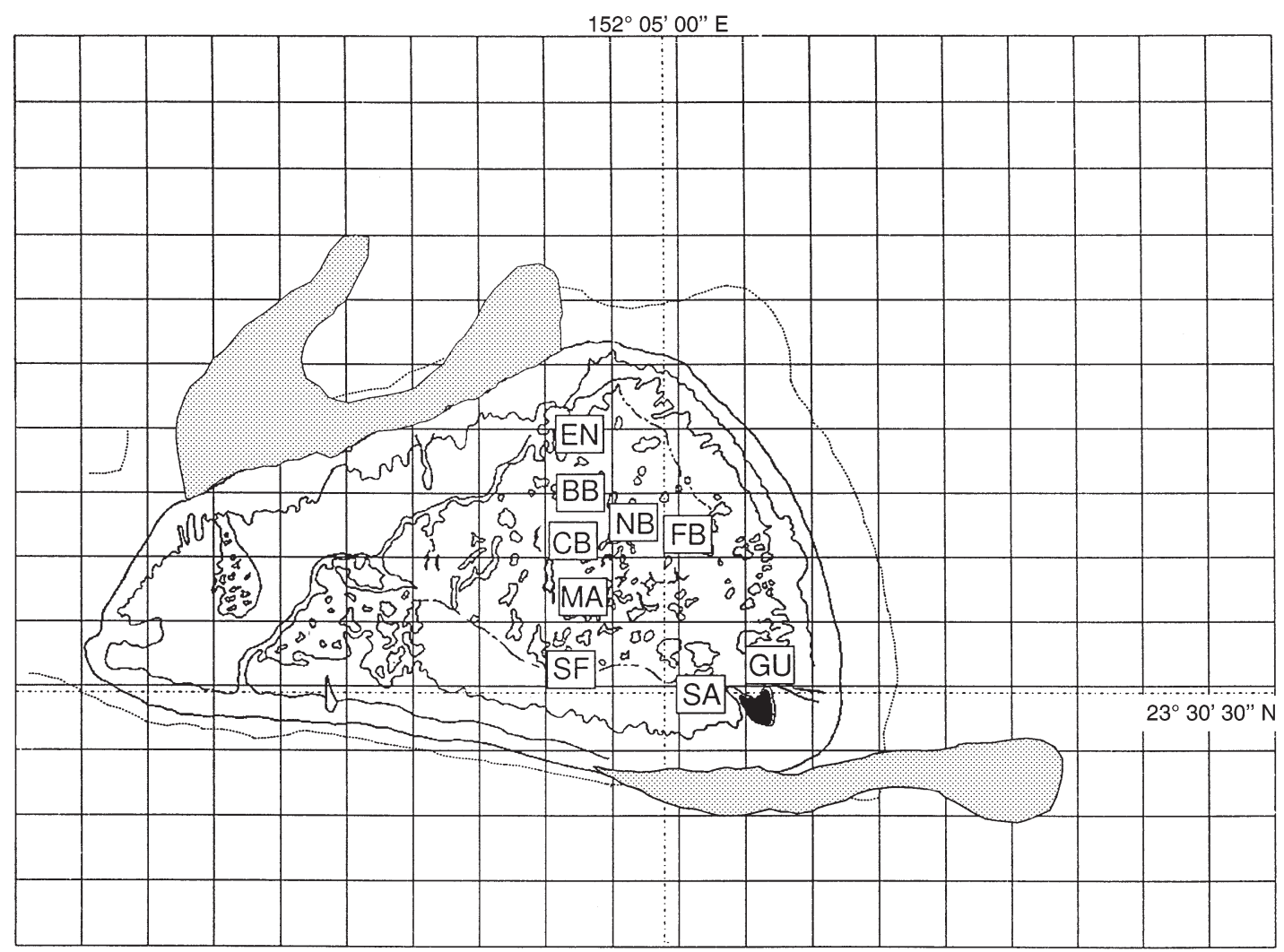

Fig. 1. Aerial map of One Tree Island (black patch) and One Tree lagoon, showing locations of 9 sites within first lagoon. BB = Big Bommies, $\mathrm{CB}=$ Centre Bommie, EN = Entrance, FB = First Bank, GU = Gutter, MA = Maze, NB = No Bommies, SA = Shark Alley,

$\mathrm{SF}=$ Sandflat. Superimposed on map are locations of major plumes (stippled areas). Scale: $0.5 \mathrm{~km}^{2}$ grids

each site, 6 permanent transects and 6 patch reefs were established for recruitment monitoring. The transects were positioned on the slopes of continuous reef 'piecrust' habitat, which was 1 to $5 \mathrm{~m}$ in depth, consisting of a wall of coral rubble interspersed with live coral heads and bordered above by the reef crest and below by a sandy bottom. Transects were $15 \mathrm{~m}$ long, and separated by $15 \mathrm{~m}$. Their width varied depending on the depth of the piecrust, but they were generally 1 to $2 \mathrm{~m}$ wide (Table 2).

The use of permanent transects of variable width was preferred to those of fixed width, since it allowed temporal changes in recruitment patterns and fate of new recruits to be followed, and gave coverage of the whole width of the piecrust reef. It was apparent that certain species settled only along the reef/sand interface and, as such, constant transect length was important. Surveyor's flagging tape was attached every $5 \mathrm{~m}$ along each transect, and a small submerged float was affixed at the start of each transect. Small patch reefs were constructed in September 1993 about $15 \mathrm{~m}$ from the start of each transect, on sand substrate in from 2 to $5 \mathrm{~m}$ depth. Each patch reef was approximately $1 \mathrm{~m} \times$
$1 \mathrm{~m} \times 0.5 \mathrm{~m}$ high, and constructed of dead coral rubble.

Recruitment surveys were conducted every $2 \mathrm{wk}$. A survey consisted of careful searches using SCUBA, within each transect and on each patch reef for recruit pomacentrids. The location (nearest metre-mark within each transect, or patch reef number) and size of each recruit was noted (length to the nearest $2 \mathrm{~mm}$, as verified by capturing and measuring a small sample of recruits).

Oceanographic and habitat features of Shark Alley. Shark Alley was identified as the location with the highest number of new recruits of a variety of species (Table 1). The objective of this part of the study was to describe aspects of the habitat quality and oceanography of this recruitment hotspot and to compare the features with other study sites using cluster analysis. Habitat quality was assessed by measuring the availability of live corals in each transect at each site. Small live branching corals (e.g., Pocillopora sp., Stylophora sp., Seriotopora sp., Acropora spp.) were expected to provide preferred habitat for new recruits (e.g., Sale et al. 1994, Ault \& Johnson 1998, D.J.B. unpubl. data). Therefore, we estimated coral density in each transect, 
Table 1. Pomacentrus spp. Comparison of pomacentrid recruitment to Shark Alley and other locations in One Tree Island lagoon since 1977. Values are means \pm SE where available

\begin{tabular}{|c|c|c|c|c|c|}
\hline \multirow{2}{*}{$\begin{array}{l}\text { Habitat, reef size, } \\
\text { depth }\end{array}$} & \multirow[t]{2}{*}{ Dates } & \multirow{2}{*}{$\begin{array}{l}\text { Frequency } \\
\text { of censuses }\end{array}$} & \multicolumn{2}{|c|}{ Densities of recruits } & \multirow[t]{2}{*}{ Source } \\
\hline & & & Shark Alley & Other sites & \\
\hline \multicolumn{6}{|c|}{ Patch reef (mean nos. per 8 reefs) } \\
\hline $\begin{array}{l}8 \text { natural patch } \\
\text { reefs }(0.94 \text { to } \\
\left.3.31 \mathrm{~m}^{3}\right) \text { per } \\
\text { location }\end{array}$ & Nov $76-$ Feb 78 & $\begin{array}{l}\text { Daily: Jan- } \\
\text { Feb } 77 ; \\
3 \text { to } 4 \text { d: Jan- } \\
\text { mid-Feb } 78 ; \\
\text { Monthly: at } \\
\text { other times }\end{array}$ & $\begin{array}{c}\text { P. nagasakiensis } \\
22 \\
\text { P. amboinensis } \\
2\end{array}$ & $\begin{array}{l}\text { P. nagasakiensis } \\
\text { Sandflat: } 13 \\
\text { First Bank: } 8 \\
\text { Centre Bommie: } 0 \\
\text { P. amboinensis } \\
\text { Sandflat: } 2 \\
\text { First Bank: } 1 \\
\text { Centre Bommie: } 0\end{array}$ & $\begin{array}{l}\text { Williams (1980), } \\
\text { Williams \& Sale } \\
(1981)\end{array}$ \\
\hline \multicolumn{6}{|c|}{ Patch reefs (nos. per patch reef) } \\
\hline $\begin{array}{l}20 \text { reefs }\left(1 \text { to } 2 \mathrm{~m}^{2}\right) \\
\text { in } 5 \mathrm{~m} \text { depth }\end{array}$ & $\begin{array}{l}\text { Apr } 84 \\
\text { Mar } 85\end{array}$ & Once & $\begin{array}{c}\text { P. amboinensis } \\
1.45 \pm 0.24(1984) \\
2.90 \pm 0.53(1985)\end{array}$ & $\begin{array}{c}\text { P. amboinensis } \\
\text { Sandflat: } \\
1.55 \pm 0.36(1984) \\
3.85 \pm 0.68(1985)\end{array}$ & Jones (1987b) \\
\hline \multicolumn{6}{|c|}{ Piecrust and Porites sp. thickets (nos. per $5 \mathrm{~m}^{2}, \mathrm{n}=3$ ) } \\
\hline $\begin{array}{l}4 \mathrm{~m}^{2} \text { quadrats, } \\
30 \mathrm{~m}^{2} \text { transects }\end{array}$ & Jan $85-$ Aug 87 & $\begin{array}{l}\text { 2-weekly to } \\
\text { 2-monthly }\end{array}$ & $\begin{array}{l}P . \text { moluccensis } \\
0.9 \pm 0.4(1985) \\
0.8 \pm 0.2(1986) \\
1.6 \pm 0.3(1987)\end{array}$ & $\begin{array}{c}\text { P. moluccensis } \\
\text { Long Bank: } \\
0.12 \pm 0.02(1985) \\
0.18 \pm 0.05(1986) \\
\text { Gutter: } \\
0.6 \pm 0.1(1984) \\
1.0 \pm 0.1(1985) \\
0.4 \pm 0.1(1986)\end{array}$ & Mapstone (1988) \\
\hline \multicolumn{6}{|c|}{ Piecrust (nos. per $5 \mathrm{~m}^{2}$ ) } \\
\hline $\begin{array}{l}6 \times 15 \mathrm{~m} \text { lengths, } \\
0 \text { to } 4 \mathrm{~m} \text { depth at } \\
\text { each site }\end{array}$ & $\begin{array}{l}\text { Oct } 93-\text { Feb } 94, \\
\text { Nov } 94-F e b 95 \\
\text { Jan } 99-\text { Feb } 99\end{array}$ & 2-weekly & $\begin{array}{l}\text { P. amboinensis } \\
0.4 \pm 0.05 \\
0.05 \pm 0.01 \\
0.4 \pm 0.12 \\
\text { P. moluccensis } \\
3.5 \pm 0.75 \\
0.3 \pm 0.03 \\
6 \pm 0.6 \\
P . \text { wardi } \\
1.5 \pm 0.02 \\
0.7 \pm 0.1 \\
1.8 \pm 0.3\end{array}$ & $\begin{array}{c}\text { All other sites combined: } \\
P . \text { amboinensis } \\
0.025 \pm 0.01 \\
0 \\
0.04 \pm 0.01 \\
P . \text { moluccensis } \\
0.5 \pm 0.05 \\
0.1 \pm 0.015 \\
2.4 \pm 0.8 \\
P . \text { wardi } \\
0.2 \pm 0.025 \\
0.15 \pm 0.01 \\
0.2 \pm 0.04\end{array}$ & This study \\
\hline \multicolumn{6}{|c|}{ Patch reefs (nos. per patch reef) } \\
\hline $\begin{array}{l}6 \times \text { rubble: } 1 \mathrm{~m} \\
\text { diam., } 2.5 \text { to } 5 \mathrm{~m} \\
\text { depth at each site }\end{array}$ & $\begin{array}{l}\text { Oct } 93-\text { Feb } 94 \\
\text { Nov } 94-\text { Feb } 95\end{array}$ & 2-weekly & $\begin{array}{c}\text { P. amboinensis } \\
3.7 \pm 0.3 \\
1.3 \pm 0.2 \\
\text { P. nagasakiensis } \\
3.5 \pm 0.2 \\
\quad 0.5 \pm 0.2\end{array}$ & $\begin{array}{c}\text { All other sites combined: } \\
\text { P. amboinensis } \\
0.2 \pm 0.03 \\
0.02 \pm 0.04 \\
\text { P. nagasakiensis } \\
0.2 \pm 0.004 \\
1.0 \pm 0.01\end{array}$ & This study \\
\hline
\end{tabular}

expressed as live cover (using point-intercept quadrats), and number of coral heads per $100 \mathrm{~m}^{2}$.

The direction of currents near the reef edge was measured with Lagrangian methodology by deploying drogues in January 1996. Each drogue had a $13 \mathrm{~cm}$ diam. float and a drogue fin that was suspended 0.2 to $0.5 \mathrm{~m}$ below the surface to minimise wind effects. Ten drogues were released just behind the reef crest near Shark Alley during flood tides, in conditions of strong onshore winds (from the southeast: 3 times) and when winds were from the northerly quarter (once only). The position of drogues was recorded every 1 to $5 \mathrm{~min}$, and positions plotted on a map derived from an aerial photo. Oceanographic features adjacent to reefs may influence patterns of settlement (Kingsford et al. 1991), so circulation patterns outside the reef and in the vicinity of Shark Alley were investigated. Tidal currents outside the lagoon run from the east to west on the 
Table 2. Transect characteristics among 9 sites in One Tree Island lagoon used for recruitment censuses. Live coral cover is given as mean $\pm \mathrm{SE}, \mathrm{n}=6$ transects, each $15 \mathrm{~m}$ long

\begin{tabular}{|lcccr|}
\hline Site & $\begin{array}{c}\text { Transect area } \\
\left(\mathrm{m}^{2}\right)\end{array}$ & $\begin{array}{c}\text { Max. depth } \\
(\mathrm{m})\end{array}$ & $\begin{array}{c}\text { \% live coral } \\
\text { cover }\end{array}$ & $\begin{array}{c}\text { Live corals } \\
100 \mathrm{~m}^{-2}\end{array}$ \\
\hline Shark Alley & 140 & 2 & $46.8 \pm 3.2$ & 195 \\
Gutter & 197 & 2.5 & $16.0 \pm 1.8$ & 41 \\
Entrance & 391 & 4.5 & $29.5 \pm 2.2$ & 112 \\
Sandflat & 151 & 2 & $21.9 \pm 1.7$ & 105 \\
First Bank & 312 & 3.5 & $11.0 \pm 0.9$ & 14 \\
Maze & 196 & 3.5 & $30.9 \pm 2.8$ & 116 \\
Centre Bommie & 202 & 2.5 & $30.5 \pm 2.7$ & 78 \\
Big Bommies & 276 & 3 & $30.1 \pm 3.1$ & 71 \\
No Bommies & 207 & 2 & $17.7 \pm 1.5$ & 54 \\
\hline
\end{tabular}

\section{RESULTS}

\section{Recruitment}

A total of 23 species of pomacentrids were recorded as new settlers on piecrust continuous reef, while only 8 species recruited to the rubble patch reefs during the study. Three species dominated recruitment in all 3 summers: Chrysiptera rollandi, Pomacentrus moluccensis, and $P$. wardi, and these species were common in all years (67\% of recruits in 1993/1994, $54 \%$ in 1994/1995 and $88 \%$ in 1999). Only 3 common species were more frequent on patch reefs than on piecrust: Chromis

flood and in the reverse on the ebb. Six drogues were released in a line, each separated by $20 \mathrm{~m}$ (measured with a $20 \mathrm{~m}$ rope tied behind the boat) on flood ( $\mathrm{n}=$ 3 times) and ebb tides ( $\mathrm{n}=3$ times). The position of drogues was plotted according to GPS (global positioning system) fixes and with respect to 3 anchored buoys of known positions (release areas in relation to Shark Alley are shown in Fig. 3). All drogues were released outside the crest near Shark Alley during northerly winds, since it was not possible to sample in this area during strong onshore winds.

Links between oceanographic and habitat features and recruitment variation among sites. A suite of oceanographic and habitat features were measured at each site to allow a dichotomous ranking of each feature at each site as follows: (1) proximity to reef crest (within or beyond $200 \mathrm{~m}$ ), (2) nearness to windward side of reef (within $45^{\circ}$ of SE vs otherwise), (3) presence of a plume (Fig. 1, from reef crest nearest to site and less than $200 \mathrm{~m}$ ), (4) proximity of a protruding surf zone versus a continuous crest, (5) amount of live coral ( $<20 \%$ vs $\geq 20 \%$ live cover).

This set of dichotomous scores was recorded for each site, and employed in a cluster analysis among sites. Clustering of sites was compared to recruitment among sites over the 3 summers of the study, to test whether a certain combination of features was present at high-recruitment sites. The dichotomy was purposefully crude, to test its possible use as a rapid assessment of potential settlement among sets of nearby sites.

In addition, wind direction over the summer 1994/1995 period was measured daily at each site, using a compass and allocating wind speed to broad categories based on 8 cardinal points. These data were used to test the prediction that Shark Alley recruitment would be highest on days when winds blew from the south-east, and that Entrance recruitment would be highest when winds blew from the north-east. nitidia, $P$. amboinensis and $P$. nagasakiensis (Table 3).

Common recruits in the 1993/1994 season were generally common in 1994/1995 and 1999 (Spearman rank coefficient with 1993/1994 recruitment: $r=0.58$ for 1994/1995; $\mathrm{p}<0.01$, and $\mathrm{r}=0.48$ for $1999 ; \mathrm{p}<0.05, \mathrm{n}=$ 23 species), although rank abundance of Chromis viridis and Dascyllus albisella recruits differed between years. Most species settled in the period December 1 to February 15 in all years, although $C$. nitidia recruits were common on patch reefs when we arrived in October-November in 1993/1994 and 1994/1995, and had likely settled in the previous month. Pulses of settlement of Pomacentrus amboinensis and P. nagasakiensis on patch reefs occurred after the main census period, probably in late February-early March, based on their sizes when observed in April-July each year.

In general, it appeared that most fish settled in the week on either side of the new moon, since settlementsized fish (<15 mm total length [TL]) were rare upon our arrival $10 \mathrm{~d}$ before the new moon for each sample trip. However, a large settlement pulse of Dischistodus melanopus apparently occurred a few days before our arrival on 6 January 1994, since high densities of individuals under $15 \mathrm{~mm}$ TL were seen at most sites, and so are likely to have settled around the full moon. This pulse dominated sightings on the piecrust for the remainder of the summer, and accounted for $>95 \%$ of the recruitment of that species over the 1993/1995 period.

Overall recruitment was lower in 1994/1995 than in 1993/1994 and 1999 for piecrust reef and 1993/1994 for patch reefs (Fig. 2, Table 3), although several species were more abundant in 1994 (Table 3). Shark Alley piecrust transects and patch reefs received more recruits than other sites, and had accumulated more recruits by the end of each season. The other 'outer' sites (Entrance, Gutter, Sandflat, First Bank) generally accumulated more recruits than the 'inner' sites (Fig. 2). Between-year correlations of recruitment 
Table 3. Total pomacentrid recruits at One Tree Island lagoon, based on weekly censuses, at 9 sites pooled ( $\mathrm{n}=54,15 \mathrm{~m}$ piecrust transects (Pie); $\mathrm{n}=54$ patch reefs (Patch)

\begin{tabular}{|c|c|c|c|c|c|}
\hline \multirow[t]{2}{*}{ Species } & \multicolumn{2}{|c|}{ Recruits 1993/1995 } & \multicolumn{2}{|c|}{ Recruits 1994/1995 } & \multirow{2}{*}{$\begin{array}{c}\text { Recruits } 1999 \\
\text { Pie }\end{array}$} \\
\hline & Pie & Patch & Pie & Patch & \\
\hline Abudefduf sp. & 0 & 0 & 1 & 0 & 0 \\
\hline Ambliglyphidodon curacao & 22 & 0 & 40 & 0 & 0 \\
\hline Chromis nitidia & 0 & 15 & 1 & 4 & 0 \\
\hline C. viridis & 20 & 1 & 0 & 0 & 0 \\
\hline Chrysiptera biocellata & 1 & 0 & 1 & 0 & 0 \\
\hline C. cyanea & 1 & 0 & 8 & 0 & 0 \\
\hline Chrysiptera rollandi & 298 & 0 & 86 & 0 & 82 \\
\hline Chrysiptera talboti & 2 & 0 & 0 & 0 & 0 \\
\hline C. trincta & 1 & 0 & 0 & 0 & 0 \\
\hline Dascyllus albisella & 10 & 0 & 0 & 0 & 12 \\
\hline Dischistodus melanopus & 140 & 3 & 3 & 2 & 43 \\
\hline Dischistodus sp. & 13 & 2 & 18 & 0 & 10 \\
\hline Neopomacentrus azysrons & 1 & 0 & 0 & 0 & 0 \\
\hline Neopomacentrus melas & 16 & 0 & 13 & 0 & 4 \\
\hline Plectroglyphidodon sp. & 0 & 0 & 1 & 0 & 0 \\
\hline Pomacentrus amboinensis & 22 & 32 & 2 & 9 & 12 \\
\hline Pomacentrus bankinensis & 3 & 0 & 3 & 0 & 0 \\
\hline Pomacentrus coelestis & 2 & 0 & 0 & 1 & 0 \\
\hline Pomacentrus flavicauda & 2 & 0 & 0 & 1 & 0 \\
\hline Pomacentrus moluccensis & 297 & 0 & 43 & 0 & 456 \\
\hline Pomacentrus nagasakiensis & 3 & 53 & 0 & 52 & 0 \\
\hline Pomacentrus vauli & 1 & 0 & 0 & 0 & 0 \\
\hline Pomacentrus wardi & 123 & 1 & 73 & 0 & 64 \\
\hline Unidentified pomacentrids & 2 & 0 & 0 & 0 & 0 \\
\hline Total & 970 & 107 & 313 & 68 & 683 \\
\hline
\end{tabular}

among the 9 sites were high (Spearman rank coefficient between 1993/1994 and 1994/1995 recruitment: $\mathrm{r}=0.86, \mathrm{n}=9, \mathrm{p}<0.05$; between 1993/1994 and 1999 recruitment: $\mathrm{r}=0.79, \mathrm{n}=9, \mathrm{p}<0.05$; and between 1994/1995 and 1999 recruitment: $\mathrm{r}=0.91, \mathrm{n}=9, \mathrm{p}<$ 0.05), emphasising the temporal persistence of spatial patterns.

\section{Shark Alley hotspot: oceanographic and habitat features}

Currents within the lagoon and in the vicinity of Shark Alley were characterised as follows. During periods of onshore winds, drogues were transported from the reef crest and into the lagoon at speeds of 17 to $22 \mathrm{~cm} \mathrm{~s}^{-1}$ (Fig. 3A). Most drogues were transported down the channel adjacent to Shark Alley, and many of them actually ran into the reef in the vicinity of Green Point in the middle of Shark Alley. For fish carried over the reef crest in this region, Shark Alley would be the first area of continuous reef and deep sand habitat (2 to $4 \mathrm{~m}$ deep) that potential settlers would encounter. When winds were from the northerly quarter, drogues were advected toward the reef crest on flood tides (10 to $22 \mathrm{~cm} \mathrm{~s}^{-1}$, Fig. 3B). Exit points over the reef crest corresponded to the position of plumes (Fig. 1).

Tidal currents were strong on the seaward side of the reef crest (Fig. 4A). On flood tides, drogues were transported in a westerly direction at speeds of 4 to $111 \mathrm{~cm}$ $\mathrm{s}^{-1}$, while ebb tide current speeds were 4 to $115 \mathrm{~cm} \mathrm{~s}^{-1}$ in the easterly direction. The great variation in speeds was due to some drogues that became stranded nearshore and others that were caught in eddies. On the ebbing tide and during northerly winds, a conspicuous plume existed approximately 150 to $200 \mathrm{~m}$ to the SW of the crest opposite Shark Alley. Some drogues that encountered the plume front near the exit point from the reef were advected into the plume and were retained in the plume for 2 to $38 \mathrm{~min}$. Circulations within the plume were further indicated by the multidirectional orientation of fixed buoys. Drogues that were released in the surf zone behind One Tree Island were advected in a rip zone toward the reef crest opposite Shark Alley. These drogues could not enter the lagoon during northerly winds, because transport was out of the lagoon near Shark Alley at these times. We presume, therefore, that fish would have to swim against 10 to $22 \mathrm{~cm} \mathrm{~s}^{-1}$ currents to settle in Shark Alley at these times, unless they traversed the entire lagoon from the northern side. Drogues that were released on 
ebb tide near the exit points of plumes were quickly advected away from One Tree Island in a northerly direction.

\section{Prevailing winds versus recruitment: Shark Alley versus Entrance}

If larvae were advected passively into the lagoon, then wind-driven surface currents may be good predictors of sites of high recruitment. Recruitment at 2 sites at opposite ends of One Tree Island lagoon, Shark Alley (SE edge) and Entrance (NE edge) was compared to wind direction, under the hypothesis that Entrance re-
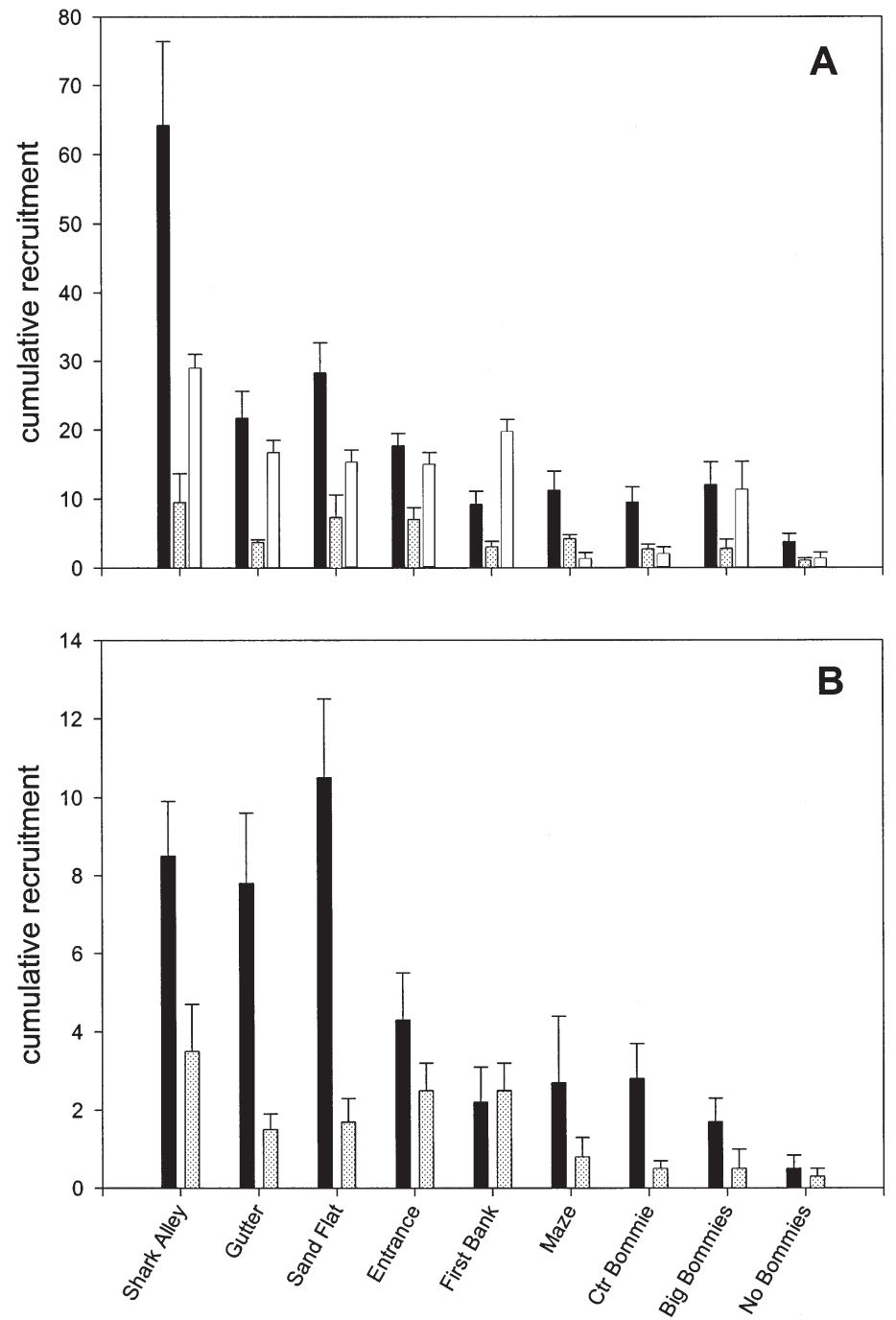

Fig. 2. Mean recruitment of pomacentrids at 9 sites in One Tree Island lagoon. Recruitment to (A) continuous (piecrust) reef (per $15 \mathrm{~m}$ transect, mean $+\mathrm{SE}, \mathrm{n}=6$; 1993/1994: black bars; 1994/1995: shaded bars; 1999: white bars), and (B) patch reefs (per reef, mean $+\mathrm{SE}, \mathrm{n}=6$; 1993/1994: black bars; 1994/1995: shaded bars) cruitment would be high under prevailing northerly winds, and Shark Alley recruitment would be high under SE winds. Southeast winds predominated on nearly $60 \%$ of sample days (Fig. 5), although most pomacen-
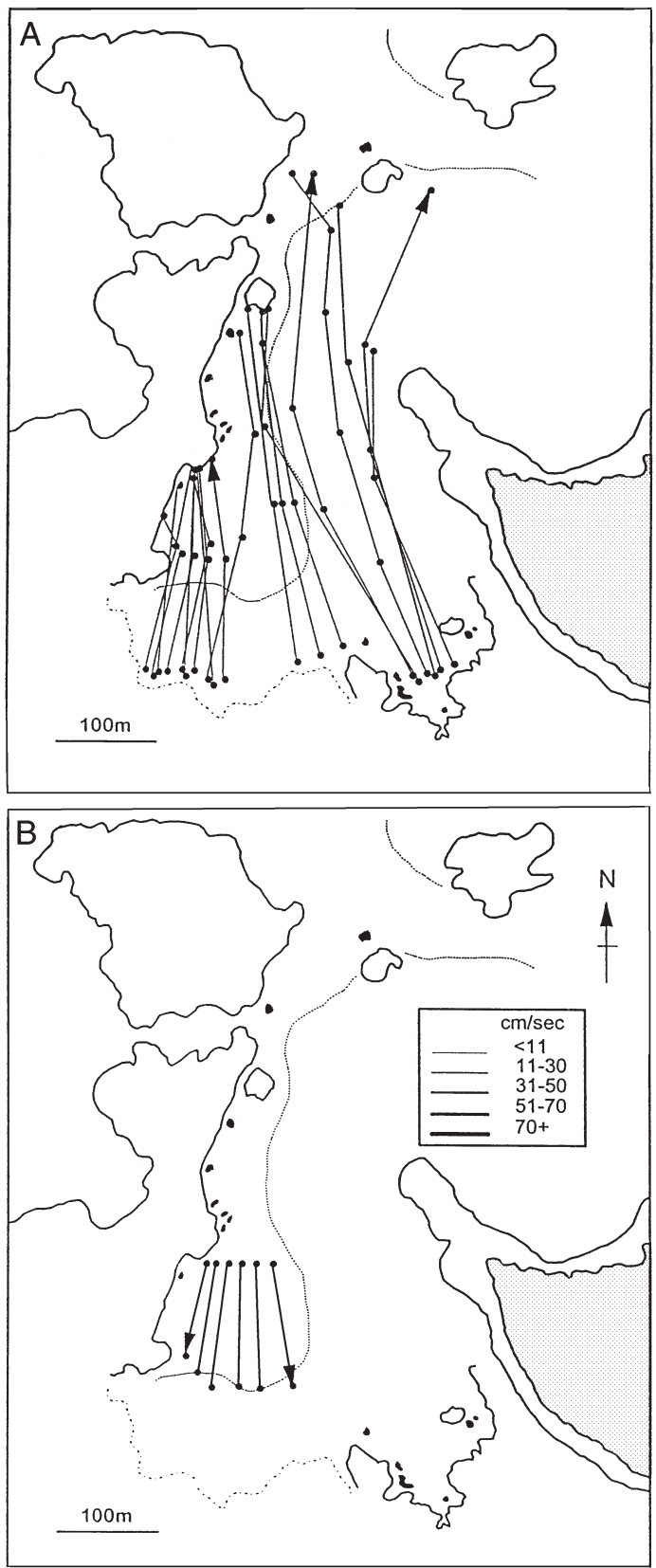

Fig. 3. Drogue tracks in vicinity of Shark Alley, One Tree Island (drogue fins $1 \mathrm{~m}$ deep). Parts of the island above the high-tide mark are stippled, width of tracks corresponds to category of current speed. Drogues advected in (A) a northerly direction at speeds ranging from 17 to $22 \mathrm{~cm} \mathrm{~s}^{-1}$, flood tide, southerly winds 15 to 20 knots, data pooled for 3 times of release, 13 to 20 January 1996, and (B) a southerly direction at speeds ranging from 10 to $22 \mathrm{~cm} \mathrm{~s}^{-1}$, flood tide, northerly winds $\sim 15$ knots, 16 January 1996 

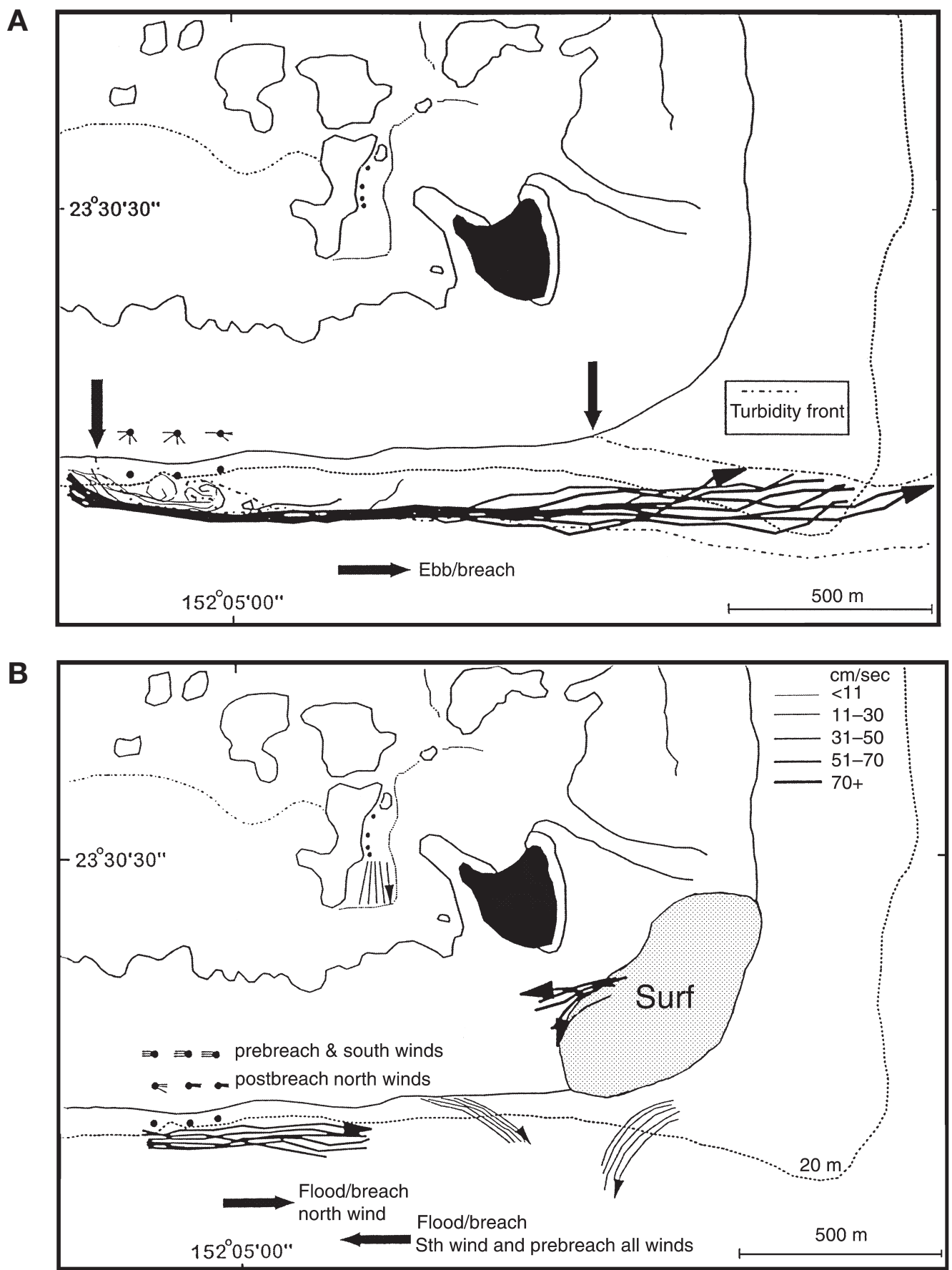

Fig. 4. Drogue tracks on reef slope (drogue fins 1 or $6 \mathrm{~m}$ deep), outside, in the vicinity of Shark Alley, One Tree Island. Parts of the island above the high-tide mark are in black; width of track corresponds to category of current speed. Dots and lines indicate direction in which lines of fixed buoys swung at 3 times of observation; breach indicates when the tide was high enough to enter ponding lagoon, prebreach when lagoon was isolated by reef crest from waters over reef slope. In general, it was not possible to release drogues on the reef crest because of shallow water, a swell, and coral boulders. (A) Drogues advected in an easterly direction at speeds ranging from 4 to $115 \mathrm{~cm} \mathrm{~s}^{-1}$, ebb tide, northerly winds 5 to 15 knots, 16-17 January 1996; very low speeds were recorded for drogues that were advected into a turbidity plume advected out of the lagoon in these conditions; some drogues were retained for up to $38 \mathrm{~min}$ despite strong west-to-east ebb flow; vertical arrows indicate edges of the region in which the ebb-tide turbidity plume exited from the reef. (B) Drogues advected in an easterly direction at speeds ranging from 5 to $68 \mathrm{~cm} \mathrm{~s}^{-1}$, flood tide, northerly winds 5 to 15 knots, 16 to 20 January 1996; very high current speeds were recorded for drogues in the rip zone of surf at the southeastern tip of the islands in surf that was $<1 \mathrm{~m} \mathrm{high}$; drogues were swept to the east and offshore of Shark Alley as waters from the lagoon were advected out of the lagoon, influenced by the wind 

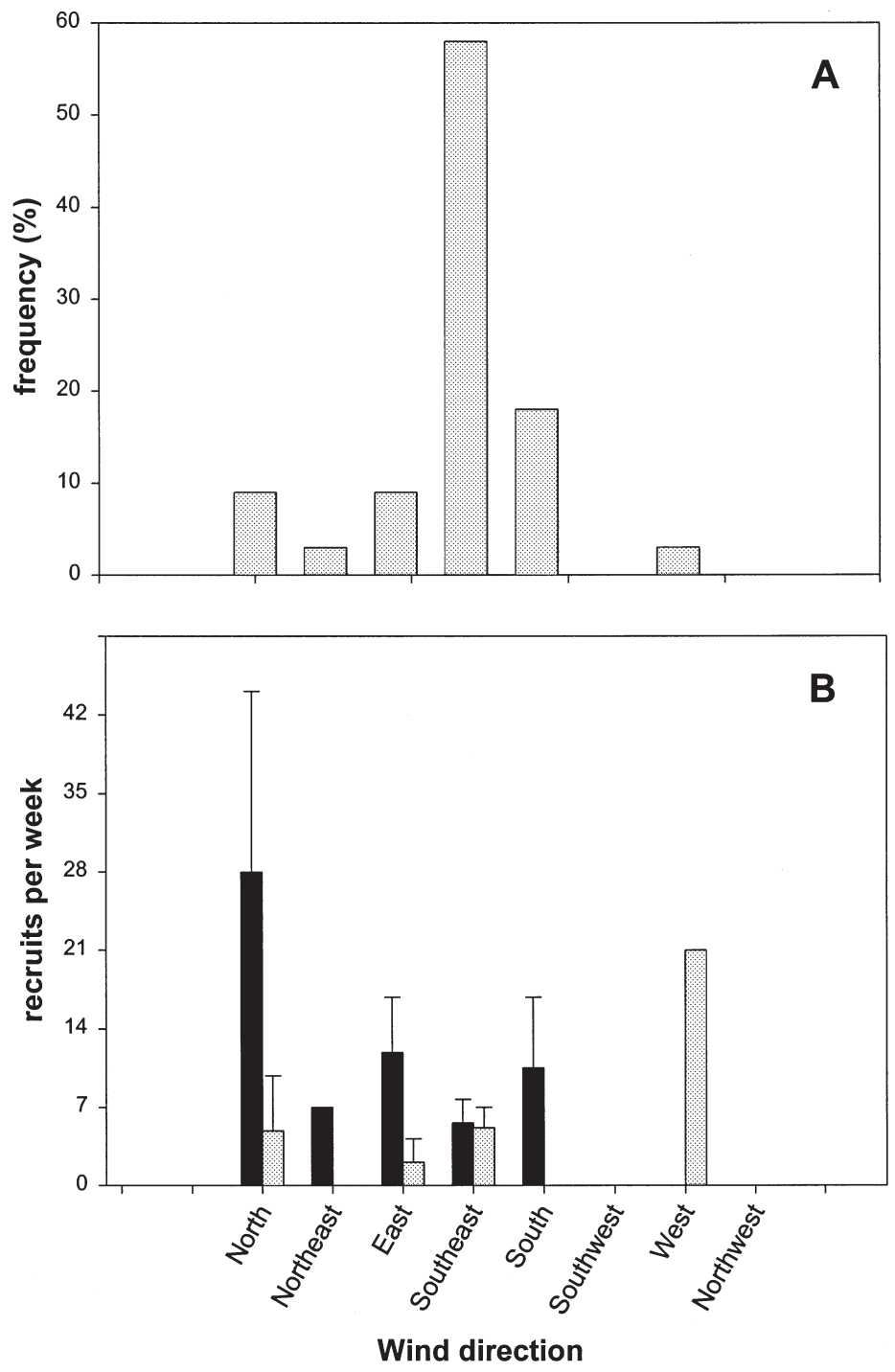

Fig. 5. (A) Predominant wind directions, and (B) recruitment of pomacentrids to Entrance (shaded bars) and Shark Alley (black bars) sites in One Tree Island lagoon during prevailing winds from November1994 to February 1995 (means + SE)

trid recruits at Shark Alley appeared in weeks with northerly winds. In contrast, most Entrance recruits appeared on rare westerly winds. Unexpectedly, on the rarer weeks of north to north-east winds (12\% of days in 1994/1995), recruitment to Shark Alley was significantly higher than on other days (Fig. $5 ; 4 \pm 2$ mean \pm $\mathrm{SE}$ vs $1.5 \pm 0.1$ recruits, Student's $t$-test, $\mathrm{p}<0.05)$.

\section{Recruitment among sites versus oceanographic and habitat differences}

The 9 sites were grouped according to a suite of 5 oceanographic and habitat factors (proximity to reef crest, nearness to windward side of reef, presence of a plume, proximity to a protruding surf zone, and amount of live coral). Dichotomous scores for each feature at each site were used, as described earlier. Outer and inner sites clustered separately, with Shark Alley closest to Entrance and Sandflat sites (Fig. 6, right). Recruitment over the study period (Fig. 6, left) showed similar grouping among sites, suggesting a link between the suite of physical and biological features and recruitment.

\section{DISCUSSION}

\section{Spatial and temporal variation in recruitment in One Tree Island lagoon}

Recruitment of pomacentrids into One Tree Island lagoon varied greatly among years and locations. Among sites, strong gradients in recruitment of most species occurred from the reef rim to the centre of the lagoon, a trend that was also noted for Pomacentrus moluccensis by B. D. Mapstone (unpubl.). Since habitat availability did not change predictably with distance from the outer rim, it alone was unlikely to account for differences. One explanation is that larvae enter the lagoon over the rim and settle in the first available habitat (but see below), as argued for fish in seagrass beds by Bell et al. (1988). Individual species differed in their recruitment patterns, suggesting that behavioural responses may override nearshore advective processes. At least one species, $P$. coelestis, avoids waters flowing out of One Tree Island lagoon, and is therefore more common on the outer slope reefs (Doherty et al. 1996). In that study, just 3 recruits of this species were counted inside the lagoon over the 2 seasons, compared to 1000 s outside.

Most species recruited in much higher densities in 1999 and 1993/1994 than in 1994/1995. For instance, Shark Alley transects supported over 300 new recruit pomacentrids by late February 1994, and 250 in February 1999, but less than 90 in February 1995. Extreme temporal patchiness of recruitment was also seen for some species. Over $95 \%$ of the entire recruitment of Dischistodus melanopus during 1993 to 1995 occurred over a few days in early January 1994, compared with more regular recruitment of this species at other locations (e.g., Lizard Island; Milicich et al. 1992). Such dramatic pulsing of recruitment has been recorded for other pomacentrids (e.g., Pitcher 1989). Of the 2 most abundant species overall, Pomacentrus moluccensis was 9 times more abundant in 1999 than in 1994/1995, and Chrysiptera rollandi was 3 times more abundant in 1993/1994 than in 
1994/1995. B. D. Mapstone (unpubl.) recorded lower (up to 2 times) temporal differences in recruitment of P. moluccensis within One Tree Island lagoon among the years 1984 to 1987.

A

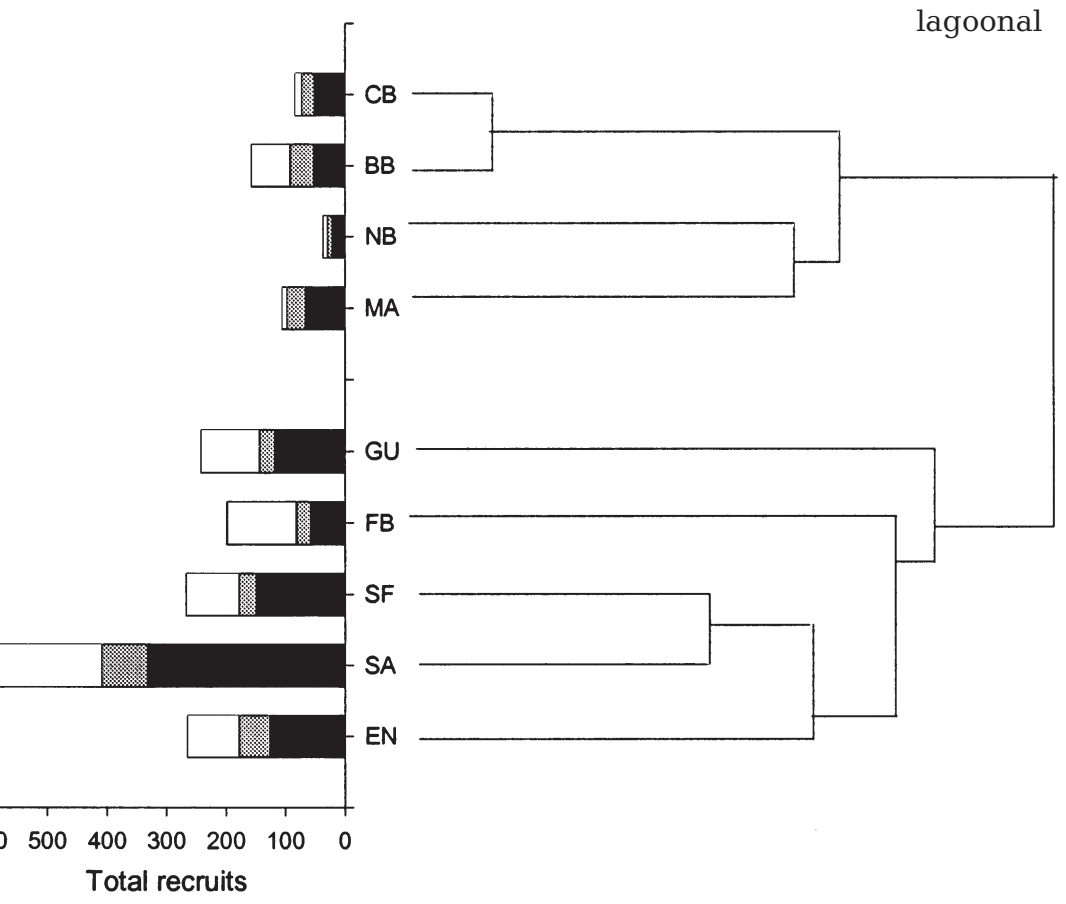

B

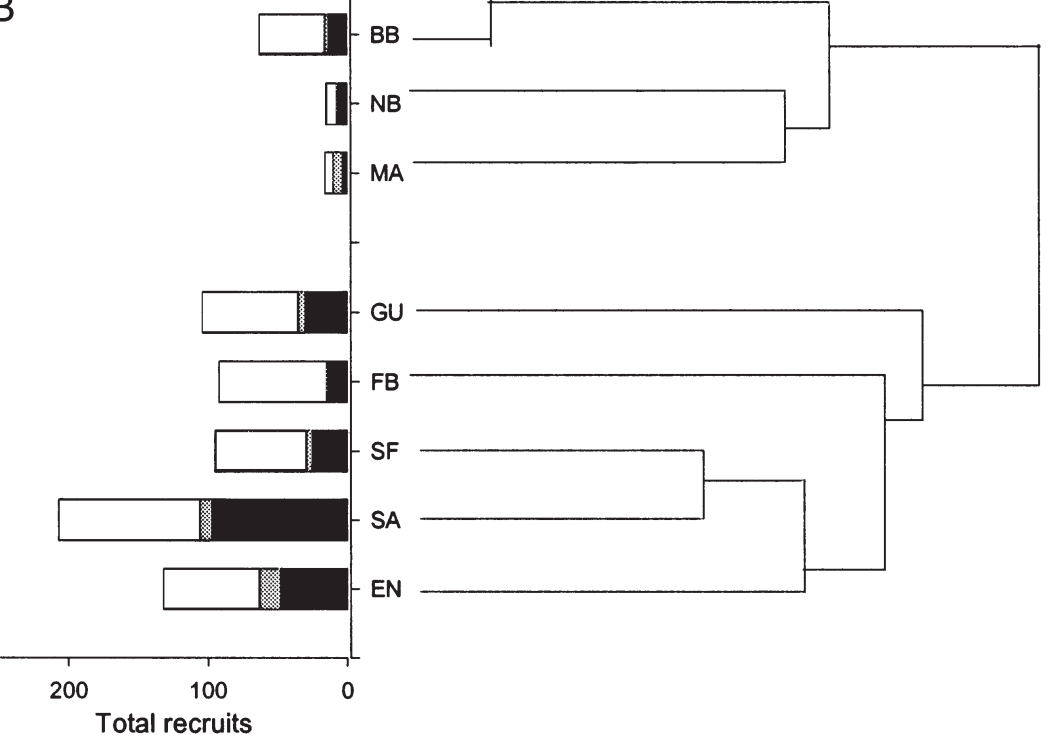

Fig. 6. Comparison of total recruitment of all pomacentrids in 3 yr (1993/1994: black bars; 1994/1995: shaded bars; 1999: white bars) for (A) all pomacentrids, and (B) Pomacentrus moluccensis, and clustering of 9 sites based on oceanographic and habitat features (proximity to reef crest, nearness to windward side of reef, presence of a plume, protrusion of a surf zone, and amount of live coral). See Fig. 1 for site abbreviations

\section{Shark Alley — a recruitment hotspot?}

Shark Alley has, at least since the mid-1970s, been a location for unusually high recruitment of pomacentrids (Table 1). Recruitment of pomacentrids was up to 20 times higher in Shark Alley than at other es in similar habitats in this study. Williams (1980) and Williams \& Sale (1981) found that Pomacentrus nagasakiensis was 2 to 4 times more common as settlers on Shark Alley patch reefs than at other sites. Although Jones (1987b) found that similar recruitment of $P$. amboinensis in Shark Alley and a nearby outer lagoon site, B. D. Mapstone (unpubl.) found that recruitment of $P$. moluccensis was higher in most years than at 2 other outer lagoon sites (see Table 1).

Despite different methodologies among these sites, it appears that Shark Alley has been a recruitment hotspot since the mid-1970s. A suite of habitat and oceanographic features may account for this uniqueness. Habitat availability may partly explain higher recruitment in Shark Alley for species such as Pomacentrus moluccensis, which prefer live corals (e.g., Sale et al. 1994, Ault \& Johnson 1998, D.J.B. unpubl. data), but not for other species. A partial explanation may also be the location of Shark Alley adjacent to a major channel linking oceanic and lagoonal waters. Larvae advected from outside would therefore pass Shark Alley before reaching other sites. However, 2 other sites (Gutter and Entrance) are adjacent to major channels, and yet their recruitment was much lower. Local oceanographic processes, including possible eddying of waters over the reef slope near Shark Alley and retention in plumes, or in the lagoon itself, may lead to higher densities of larvae near the site than elsewhere. A small eddy adjacent to transects in Shark Alley was noticed during this study (D.J.B. pers. obs.), and this phenomenon was not noticed at other sites.

Peaks of settlement at Shark Alley were often, surprisingly, when winds were predominantly from the north, generating a net water flow out of Shark Alley channel (see Fig. 4). At 
these times, currents of up to $30 \mathrm{~cm} \mathrm{~s}^{-1}$ flow out of the lagoon as a plume. This suggests an element of active swimming if fish enter from the SE side. Large presettlement pomacentrids are capable of swimming against currents in the range of 5 to $30 \mathrm{~cm} \mathrm{~s}^{-1}$ (Stobutzki \& Bellwood 1997) and may use the plume as a cue to seek reefal or lagoonal waters. We also argue that the presence of surf zones may also play an important role in transport. Reef fishes at the time of settlement are known to swim through surf zones (e.g., Doherty \& Mcllwain 1996), but transport processes associated with surf zones have received little attention compared to surf beaches. Rip currents generated by surf zones on beaches affect coastal waters at spatial scales of metres to kilometres (Short 1993), but have been largely ignored on coral reefs. Surf zones that are found on topographic protrusions may be particularly important, such as at the rear of One Tree Island, where waters are captured and funnelled to the reef crest near Shark Alley and the Gutter (Fig. 4B). This mechanism is likely to be most important on areas of reef on or near to the windward side or during surge-pulse events at others.

\section{Predicting recruitment using simple oceanographic and habitat features}

When oceanographic and habitat factors were combined using cluster analyses, sites of highest recruitment over 3 seasons grouped together for all pomacentrids (Fig. 6A), and for one of the most common species, Pomacentrus moluccensis (Fig. 6B), indicating that such simple categories may prove useful in predicting sites of highest recruitment on reefs. It also suggested that unifactorial studies of recruitment, or studies that consider only one class of predictive variable (e.g., such aspects as larval supply, habitat availability or oceanography alone) are unlikely to be of great predictive value. For instance, while 'outer' sites in this study generally received higher recruitment than sites in the lagoon centre, the use of a simple predictor such as distance from the edge of the lagoon would not have identified the Shark Alley hotspot among the other 4 outer sites.

Models such as that proposed here may be useful in determination of likely sinks of larvae, and how these may change temporally as values for some of the predictive features change (e.g., wind direction, swell height). The model indicates that the Shark Alley recruitment hotspot is a function of a suite of features, both oceanographic and habitat-related, leading to higher supply of potential settlers than adjacent sites. The interannual persistence of high recruitment at Shark Alley may therefore be related to the persis- tence of these features over long time scales. The characteristics of physical features such as plumes, presence of surf zones and prevailing winds have been stable over the last few years at least (M.J.K. unpubl. data), although a major coral bleaching event in 1998 impacted some sites within One Tree Island lagoon (D.J.B. unpubl. data). However, the ranking of sites in terms of live coral cover was not affected. The analysis of physical factors versus recruitment was purposefully crude, to allow us to explore its usefulness as a 'rapid assessment' technique for identifying locations on a reef that may receive high recruitment. Further verification at other reefs and with other fish taxa will be required to assess its usefulness as a predictive model.

Acknowledgements. The study was made possible by a grant from the Australian Research Council (M.J.K., P.J.D.). D.J.B. was supported by an ARC Postdoctoral Fellowship, and logistic support was provided by the Australian Institute of Marine Science and the University of Sydney. We thank John Carleton, Kim Smith, Natalie Bridge, Robert Dockerill, Sean Connell and Jane Harris for assistance, and the staff of One Tree Island Research Station for support. We are grateful for the comments of 2 anonymous reviewers.

\section{LITERATURE CITED}

Anderson GRV, Ehrlich AH, Ehrlich PR, Roughgarden JD (1981) The community ecology of coral reef fishes. Am Nat 117:476-495

Ault TR, Johnson CR (1998) Spatially and temporally predictable fish communities on coral reefs. Ecol Monogr 68(1):25-50

Bell JD, Steffe AS, Westoby M (1988) Location of seagrass beds in estuaries: effects on associated fish and decapods. J Exp Mar Biol Ecol 122:127-146

Booth DJ (1992) Larval settlement patterns and preferences by domino damselfish Dascyllus albisella Gill. J Exp Mar Biol Ecol 155:85-104

Booth DJ, Beretta GA (1994) Seasonal recruitment, habitat associations and survival of pomacentrid reef fish in the US Virgin Islands. Coral Reefs 13:81-89

Booth DJ, Wellington G (1998) Settlement preferences in coral-reef fishes: effects on patterns of adult and juvenile distributions, individual fitness and population structure. Aust J Ecol 23:274-279

Doherty PJ (1982) Some effects of density on the juveniles of two species of tropical, territorial damselfishes. J Exp Mar Biol Ecol 65:249-261

Doherty PJ (1983) Tropical territorial damselfishes: is density limited by aggression or recruitment? Ecology 64:176-190

Doherty PJ (1991) Spatial and temporal patterns in recruitment. In: Sale PF (ed) The ecology of fishes on coral reefs. Academic Press, London, p 261-293

Doherty PJ, Mcllwain J (1996) Monitoring larval fluxes through the surf zones of Australian coral reefs. Mar Freshw Res 47:383-390

Doherty PJ, Williams DMcB (1988) The replenishment of coral reef fish populations. Oceanogr Mar Biol Annu Rev 26: 487-551

Doherty PJ, Wolanski E, Carleton J (1997) Directional swimming of fish larvae determines connectivity of fish popula- 
tions on the Great Barrier Reef. Naturwissenschaften 84: 262-268

Doherty PJ, Kingsford MJ, Booth DJ, Carelton J (1996) Habitat selection before settlement by Pomacentrus coelestis. Mar Freshw Res 47:391-400

Galzin R, Planes S, Dufour V, Salvat B (1994) Variation in diversity of coral reef fish between French Polynesian atolls. Coral Reefs 13:175-180

Green AL (1996) Spatial, temporal and ontogenetic patterns of habitat use by coral reef fishes (family Labridae). Mar Ecol Prog Ser 133:1-11

Jones GP (1987a) Some interactions between residents and recruits in two coral reef fishes. J Exp Mar Biol Ecol 114: $169-182$

Jones GP (1987b) Competitive interactions among adults and juveniles in a coral reef fish. Ecology 68:1534-1547

Kingsford MJ, Finn M (1997) The influence of phase of the moon and physical processes on the input of presettlement fishes to coral reefs. J Fish Biol 51(Suppl A):176-205

Kingsford MJ, Wolanski E, Choat JH (1991) Influence of tidally-induced fronts and langmuir circulations on distribution and movements of presettlement fish around a coral reef. Mar Biol 109:167-180

Ludington CA (1979) Tidal modifications and associated circulation in a Platform Reef Lagoon. Aust J Mar Freshw Res 30:425-430

Mapstone BD (1988) The determination of patterns in the abundance of Pomacentrus moluccensis Bleeker on the southern Great Barrier Reef. PhD thesis, University of Sydney

Milicich MJ, Meekan MG, Doherty PJ (1992) Larval supply: a good predictor of recruitment of 3 species of coral reef fish (Pomacentridae). Mar Ecol Prog Ser 86:153-166

Pitcher CR (1989) Spatial variation in the temporal pattern of recruitment of a coral reef damselfish. Proc 6th Int Coral Reef Symp 2:811-816

Editorial responsibility: Charles Birkeland (Contributing Editor), Mangilao, Guam
Russell BC, Anderson GRV, Talbot FH (1977) Seasonality and recruitment of coral reef fishes. Aust J Mar Freshw Res 28:521-528

Sale PF, Guy JA, Steel WJ (1994) Ecological structure of assemblages of coral reef fishes on isolated patch reefs. Oecologia 98:83-99

Short AD (1993) Beach and surf zone morphodynamics. J Coast Res (Spec Iss) 15:1-31

Stobutzki I, Bellwood DR (1997) Sustained swimming abilities of the late pelagic stages of coral reef fishes. Mar Ecol Prog Ser 149:35-41

Sweatman HPA (1985) The influence of adults of some coral reef fishes on larval recruitment. Ecol Monogr 55:469-485

Tolimieri N (1995) Effects of microhabitat characteristics on the settlement and recruitment of a coral reef fish at two spatial scales. Oecologia 102:52-63

Wellington GM (1992) Habitat selection and juvenile persistence control the distribution of two closely related Caribbean damselfishes. Oecologia 90:500-508

Wellington GM, Victor BC (1985) El Niño mass coral mortality: a test of resource limitation in a coral reef damselfish population. Oecologia 68:15-19

Williams DMcB (1979) Factors influencing the distribution and abundance of pomacentrids (Pisces; Pomacentridae) on small patch reefs in One Tree lagoon (Great Barrier Reef). PhD thesis, University of Sydney

Williams DMcB (1980) Dynamics of the pomacentrid community on small patch reefs in One Tree lagoon (Great Barrier Reef). Bull Mar Sci 30:159-170

Williams DMcB (1991) Patterns and processes in the distribution of coral reef fishes. In: Sale PF (ed) The ecology of fishes on coral reefs. Academic Press, London, p 437-474

Williams DMcB, Sale PF (1981) Spatial and temporal patterns of recruitment of juvenile coral reef fishes to coral habitats within 'One Tree Lagoon', Great Barrier Reef. Mar Biol 65:245-253

Submitted: May 6, 1999; Accepted: January 6, 2000

Proofs received from author(s): August 2, 20000 